\title{
Usaha Mochammad Natsir di Bidang Pendidikan dalam Memajukan Ummat Islam Indonesia 1950-1960
}

\author{
Imas Emalia ${ }^{1}$
}

\begin{abstract}
Abstrak
Artikel ini dimaksudkan sebagai usaha merekonstruksi sejarah pemikiran dari seorang sosok politikus terkenal yang lembut, tegas, dan islami, yakni Mochammad Natsir. Pemikirannya tentang pendidikan adalah sebagai perjuangannya dalam memperhatikan nasib rakyat Indonesia, terutama ummat Islam. Tulisan ini hanya menyoroti Pemikiran Mochammad Natsir tentang pendidikan, pemikirannya ini selain lewat dakwah, berpolitik, juga lewat tulisantulisan baik berupa buku, atau pemberitaan-pemberitaan dan artikel-artikel dalam surat kabar, terutama harian Abadi, yaitu surat kabar harian milik Partai Islam Masyumi. Dengan menganalisa artikel dan pemberitaan yang terdapat dalam surat kabar harian Abadi milik Partai Masyumi antara tahun 1950-1960 tentang konsep pendididkan Islam dari Mochammad Natsir. Sebagai pemimpin politik Islam, Mochammad Natsir secara maksimal telah memberikan seluruh tenaga dan pikirannya demi kepentingan ummat Islam di Indonesia dan seluruh bangsa Indonesia. Mochammad Natsir, menggagas konsep dakwah Islam bukan sekedar menyampaikan ajaran Islam, tetapi amar ma'ruf nahi munkar yang di dalamnya mengandung tiga unsur utama yaitu amal perbuatan lisan, aktualisasi ajaran Islam dengan karya nyata, dan kepribadian yang terpuji sebagai sokogurunya.
\end{abstract}

Kata Kunci: Mochammad Natsir, Pemikiran Pendidikan, 1950-1960

\begin{abstract}
This study aims to reconstruct the history of thought of a well-known, gentle, decisive, and islamic politician figure, Mochammad Natsir. His thoughts on Islamic education is his struggle to pay attention to the fate of Indonesian people, especially Muslims. This study highlights Mochammad Natsir's thought on education through da'wah (the preaching of Islam), his political enggagement, and his writings in the form of books, news, as well as articles in newspapers, especially daily newspaper owned by Partai Islam Masyumi (Islamic Party Masyumi) between 1950-1960. As Islamic political figure, Mochammad Natsir has optimally contributed his energy and thought to the Muslim community in Indonesia especially, and Indonesian people generally. Mochammad Natsir thinks that Islamic preaching is not merely delivering Islamic teachings, but also amar ma'ruf nahi munkar which consists of three primary elements, namely verbal deeds, the actualization of the Islamic teachings with the real work, and commendable personality as the pillar. According to him, Muslim has to be free from poverty, suffer, ignorance, illiterate, blind heart, and oppresion. Therefore, they have to refer to the Koran and hadith in social life.
\end{abstract}

Key Words: Mochammad Natsir, Education of Thought, 1950-1960

\footnotetext{
${ }^{1}$ Sejarah Peradaban Islam Fakultas Adab dan Humaniora UIN Syarif Hidayatullah Jakarta.
} 


\section{A. Pendahuluan}

Berdirinya partai-partai Islam pada masa kemerdekaan perlu dilihat dengan latar belakang politik di Indonesia pada masa-masa tersebut. Kondisi bangsa Indonesia pada awal abad XX berada dalam kemiskinan, kesengsaraan, kefakiran, keterbelakangan pendidikan, dan kesenjangan sosial yang tinggi. Walaupun penduduk Indonesia mayoritas beragama Islam, pada saat itu, kedudukan ummat Islam pada masa permulaan revolusi tidak dapat disebut kuat. Hal ini tercermin dalam kabinet dan KNIP, hanya dua orang yang mewakili mereka dalam Kabinet (Presidensial) yang dibentuk pada bulan Agustus 1945 dan hanya 20 dari 137 anggota KNIP. Kedua menteri tersebut adalah Abikusno Tjokrosujoso (Pekerjaan Umum) dan K.H.A.Wahid Hasjim (Menteri Negara). Dalam Kabinet ini hanya satu orang dari partai Masyumi yang duduk, yaitu Haji Mohammad Rasjidi, yang ditugasi menghadapi soal-soal agama. Pada tanggal 3 Januari 1946 Mohammad Natsir dari Partai Masyumi diangkat sebagai menteri penerangan. ${ }^{2}$

Adanya partai-partai Islam itu, yang muncul sejak awal Revolusi dan semakin berpengaruh pada masa Demokrasi Liberal, menjadikan partaipartai Islam tersebut sebagai tumpuan bagi pembangunan ummat Islam ke arah yang lebih baik dan sejahtera. Bagi ummat Islam Indonesia kemiskinan haruslah diperhatikan dan diprihatinkan untuk kemudian diatasi atau dicarikan solusinya. Hal ini karena mereka yang berada di garis kemiskinan tidak hanya menderita secara riil, tetapi juga secara psikologis. Kemiskinan membuat

\footnotetext{
${ }^{2}$ Deliar Noer, Partai Islam di Pentas Nasional: Kisah dan Analisis Perkembangan Politik Indonesia 1945-1965, (Bandung, Mizan, 2000), h. 159-162.
}

mereka tidak mampu menyekolahkan anak-anaknya. Kemiskinan membuat mereka terbelakang dan terpuruk dalam peradaban.

Menurut Mochammad Natsir, dengan memperjuangkan pembangunan ekonomi dapat juga memperjuangkan tingkat pendidikan ummat dalam rangka mencerdaskan bangsa dan menjalankan tugas mulia untuk mengajak ummat ke jalan yang lebih beradab. Perjuangan pendidikan Islam yang ditegakkan oleh Mochammad Natsir ini dapat dilihat dari hasil Kongres Masyumi tahun 1952 yang mengesahkan beberapa program perjuangan Masyumi yang ingin ditegakkan dalam hidup bernegara. Program perjuangan Masyumi tersebut terbagi ke dalam tujuh bagian, yaitu: kenegaraan, perekonomian, keuangan, sosial, pendidikan dan kebudayaan, luar negeri, dan Irian Barat.

Dalam bidang pendidikan, program Masyumi menetapkan bahwa program pendidikan yang diberikan di sekolahsekolah, atau lembaga-lembaga pendidikan lainnya baik formal maupun non-formal, hendaknya diimbangi dengan agama. Pendidikan yang diselaraskan dengan agama akan membentuk watak dan kepribadian masyarakat yang berakhlak dan bersusila. Dalam bukunya, Deliar Noer menjelaskan tentang program pendidikan Partai Masyumi ini, sebagai berikut:

Sekolah swasta agama perlu diberi subsidi. Pengajaran rendah dan menengah hendaknya juga menumbuhkan keterampilan anak, di samping pengetahuan. Pendidikan agama di sekolah pemerintah ditujukan untuk pembentukan watak dan kepribadian sehingga para pemuda menjadi anggota masyarakat yang bertanggung jawab, berjiwa masyarakat, berdisiplin, dan berkesusilaan. Pemuda yang berbakat tetapi tidak mampu harus diberi beasiswa yang cukup. Pendidikan jasmani perlu diperluas dan mutunya perlu dipertinggi. Pendidikan 
ruhani diselenggarakan menurut agama masing-masing. Gerakan kebudayaan dibimbing pemerintah ke "arah budi dan watak yang luhur". Gerakan pemuda termasuk kepanduan, perlu dimajukan dan dibantu. $^{3}$

Berasarkan cita-cita dan pandangan Partai Masyumi dalam program pendidikan tersebut, kemudian Mochammad Natsir selalu memperhatikan nasib rakyat Indonesia dan terutama sesama ummatnya. Mochammad Natsir berusaha mengamalkan apa yang diajarkan dalam agama Islam bahwa di dalam Al-Qur'an surat Al-Mujadilah (QS. 58: 11) disebutkan "...Allah akan mengangkat (derajat) orang-orang yang beriman dan orang-orang yang diberi ilmu beberapa derajat". Dari ayat tersebut Mochammad Natsir menyimpulkan bahwa bangsa menurut agama Islam adalah suatu ummat yang harus menuntut ilmu selama hidupnya untuk menggapai kemuliaan dan jauh dari kebodohan serta penindasan, manusia harus selalu berusaha untuk bekerja dan sabar dalam menuntut ilmu dan mengamalkan dari ilmu-ilmu yang didapatnya.

Menurut Mochammad Natsir, Islam bukanlah hanya sekedar agama yang ajarannya harus diajarkan sebagai ilmu pengetahuan, akan tetapi harus dihayati dan diamalkan. Menurutnya ajaran Islam juga berbeda dari sekedar pendidikan budi pekerti dan tingkah laku, karena ajaran Islam wajib dipraktikkan. Praktik dari ajaran Islam ini akan terbiasa apabila di sekolahsekolah digalakan praktik kehidupan sesuai dengan tuntunan agama Islam. ${ }^{4}$

Walaupun perjuangan Mochammad Natsir dalam memajukan

\footnotetext{
${ }^{3}$ Deliar Noer, Partai Islam di Pentas Nasional, h. 150-151.

${ }^{4}$ Deliar Noer, Partai Islam di Pentas Nasional, h. 468-469.
}

peradaban ummat Islam terutama di bidang pendidikan terus dilakuakan akan tetapi respon pemerintah sangat lambat dalam menerapkan materi keagamaan dalam kurikulum sekolah. Baru pada tahun 1950-an, agama, terlebih agama Islam dijadikan mata pelajaran wajib di sekolah-sekolah. Bahkan di kalangan orang-orang Islam sekalipun, masih banyak yang menganggap bahwa agama adalah urusan pribadi, dan menjadi tanggung jawab orang tuanya dalam mengajarkan agama kepada anakanaknya yang selaku murid dari sekolahsekolah yang ada di lingkungannya.

Selain itu antara tahun 1950-1960, kalangan ummat Islam sendiri belum banyak menyediakan jumlah guru agama yang cukup dan cakap terlebih untuk membina sekolah yang membaurkan pelajaran agama dengan pengetahuan umum. Sekolah-sekolah dan universitasuniversitas yang didirikan organisasiorganisasi Islam pun masih sebatas menempatkan agama sebagai sekedar pelajaran saja.

Padahal menurut Mochammad Natsir sudah selayaknya bahwa tugas membaurkan agama dengan pengetahuan umum merupakan dakwah yang mulia yang menjadi kewajiban bagi setiap muslim. Memang sejak tahun 1946, Departemen Agama telah didirikan, dan mengurusi masalah yang berkaitan dengan agama, walaupun pada akhirnya mengurusi hal yang lebih kompleks, seperti mengurusi bidang penerangan, pendidikan, dan pengadilan. Departemen Agama mengawasi pendidikan agama di sekolah-sekolah mulai tingkat dasar sampai universitas, yang kemudian berhasil mendirikan Institut Agama Islam Negeri sekitar tahun 1960 setelah dipersiapkan sebelumnya sejak tahun $1953{ }^{5}$

\footnotetext{
5 Deliar Noer, Partai Islam di Pentas Nasional, h. 362-363.
} 
Akan tetapi dakwah menyeru kepada kebaikan dengan mengamalkan ajaran-ajaran agama Islam adalah sebagai sifat yang logis dari penjabaran ajaran Islam yang tidak hanya dilakukan segolongan ummat Islam ataupun lembaga-lembaga, melainkan oleh individu, sebagaimana tercantum dalam Al Qur'an surat Ali Imran ayat 104 yang artinya sebagai berikut: "dan hendaklah ada di antara kamu segolongan umat yang menyeru kepada kebajikan, menyuruh kepada yang ma'ruf dan mencegah dari yang munkar, merekalah orang-orang yang beruntung."

\section{B. Pembahasan}

\section{Konsep dan Perjuangan Mochammad Natsir dalam Bidang Pendidikan}

Menurut Mochammad Natsir, dakwah dalam arti amar ma'ruf nahi munkar, adalah syarat mutlak bagi kesempurnaan dan keselamatan hidup masyarakat, dan dalam rangka mengabdi kepada Yang Maha Pencipta. Inilah yang menjadi kewajiban manusia di dunia sebagai makhluk sosial yang ditegaskan dalam Al-Qur'an dan Hadits. Seperti yang dijelaskan dalam Al-Qur'an surat Adz-Dzariat ayat 56 (Q.S. 51/56), yang artinya: "Dan Aku tidak menciptakan jin dan manusia melainkan supaya mereka menyembah-Ku".

Perjuangan Mochammad Natsir dalam bidang pendidikan diawali ketika ia aktif di Persis (Persatuan Islam) yang ada di Bandung, tahun 1927. Organisasi ini bergerak di bidang sosial keagamaan dan pendidikan, sebagaimana tujuan didirikan Persis yang tertulis dalam Anggaran Dasar Persis Pasal IV, yaitu:

"Untuk memperjuangkan berlakunya hukum-hukum Islam dan ajaran Islam yang berdasarkan Al-Qur'an dan As-Sunah, dalam masyarakat". Usaha ini juga dijelaskan dalam Anggaran Dasar Persis Pasal V, yaitu: "Berusaha mengembalikan kaum muslimin kepada Al-Qur'an dan As-
Sunah, menghidupkan roh jihad dan ijtihad dalam kalangan ummat, memperluas tersiarnya tablig dan dakwah Islam kepada segenap lapisan masyarakat, mendirikan madrasah dan pesantren untuk mendidik generasi Islam dengan Al-Qur'an dan AsSunah". 6

Selain itu beberapa program pendidikan yang direncanakan organisasi ini adalah karena hasil dari musyawarah antara pimpinan Persis, yaitu A. Hasan dan Mochammad Natsir. Program tersebut antara lain: ${ }^{7}$

1. Memenuhi kekurangan pelajaran bagi generasi muda mengingat mereka haus sekali terhadap pengetahuan modern dan sesuai pula dengan penghematan pemerintah dalam pendidikan.

2. Mengatur pendidikan dan pengajaran generasi muda dengan berdasar kepada jiwa Islam dan mempraktikkannya secara lebih rapi.

3. Mengatur dan menjaga pendidikan generasi muda agar mereka tidak bergantung kepada gaji dan honor setelah ke luar dari sekolah dan dapat bekerja dan percaya kepada kemampuan sendiri.

Dalam merealisasikan tujuan tersebut Persis banyak medirikan sekolah, seperti Taman Kanak-Kanak, HIS, MULO, pertukangan dan perdagangan, kursus-kursus, dan ceramah-ceramah. Dalam mengembangkan pendidikan tersebut Persis selalu melibatkan Mochammad Natsir baik dalam bentuk pengelolaan maupun dalam perintisan. Bahkan pada tahun yang sama, yaitu 1930, seorang anggota Persis yang bernama A. A.

6 Thohir Luth, Dakwah dan Pemikiran Muhammad Natsir, (Jakarta, Gema Insani Press, 1999), h. 32.

7 Thohir Luth, Dakwah dan Pemikiran Muhammad Natsir, h. 37. 
Banama mendirikan sekolah yang diberi nama 'Pendidikan Islam', dan 2 tahun kemudian, yaitu tahun 1932 kepemimpinan sekolah ini kemudian diserahkan kepada Mochammad Natsir. Hal ini karena Mochammad Natsir selalu aktif dan sering mengikuti A. Hasan dalam acara-acara yang dianggap penting dan menguntungkan bagi perkembangan Persis. Maka sejak itu pula Mochammad Natsir memprakarsai berdirinya Taman kanak-Kanak dan HIS di Bandung.

Aktivitas Mochammad Natsir dalam pengelolaan, perintisan, dan pengajaran di lembaga-lembaga pendidikan organisasi Persis ini seperti ditulis dalam buku karya Syafiq A. Mughni, yaitu "Hassan Bandung Pemikir Islam Radikal", yang dikutif oleh Thohir Luth, sebagai berikut:

"Di samping itu, didirikan pula lembaga pendidikan berupa pesantren dengan nama "Pesantren Persatuan Islam" di Bandung pada bulan Maret 1936, sebagai hasil pertemuan di Mesjid Persatuan Islam Jalan Pangeran Sumedang, Bandung. Pengurus dan guru-gurunya terdiri atas orang-orang yang dengan sukarela mengorbankan waktu dan tenaganya untuk pesantren. Mereka itu antara lain $R$. Abdul Kadir (alumnus Sekolah Teknik Bandung) yang mengajar ilmu teknik, M. Natsir yang mengajar ilmu pendidikan di samping penasihat, serta Hassan yang merangkap sebagai kepala pesantren."

Itulah Mochammad Natsir yang selalu mengorbankan waktu dan tenaganya untuk kepentingan ummat. Bagi Mochammad Natsir, aktifitas di bidang pendidikan adalah sebagai salah satu wahana dakwah Islam. Tujuan Mochammad Natsir sendiri berjuang di dunia pendidikan merupakan bagian dari pembinaan ummat Islam dalam

8 Thohir Luth, Dakwah dan Pemikiran Muhammad Natsir, h. 40. menanamkan nilai-nilai akidah, melatih, dan membekali ilmu pengetahuan serta keterampilan sehingga generasi Islam kelak memiliki iman dan Islam yang kuat. Hal ini seperti yang dilakukan Mochammad Natsir ketika memberi pendidikan dan pelatihan kepada para da'i yang disiapkan untuk berdakwah di desa-desa terpencil, daerah-daerah transmigrasi, dan daerah-daerah yang rawan pengaruh Kristenisasi.

Menurut Yusuf Abdullah Puar, seperti yang dikutif Thohir Luth, bahwa suksesnya Persis di bidang pendidikan adalah karena keterlibatan Mochammad Natsir, berikut ungkapannya:

"Motivasi M. Natsir terjun ke lapangan pendidikan yang dilaksanakan Persis ialah suatu pemikiran dan cita-cita hendak membangun suatu sistem pendidikan yang sesuai dengan hakekat ajaran Islam. Hal ini sebagai akibat sistem pendidikan yang pincang dari kolonial Belanda dan sistem pendidikan Indonesia sendiri dalam pesantren dan madrasah yang tidak memenuhi hajat-hajat atau keinginan masyarakat pada zaman itu.",

Keberadaan Mochammad Natsir ini adalah sebagai lentera bagi Persis dalam memperjuangkan ummat Islam Indonesia baik di bidang sosial keagamaan dan pendidikan. Dalam pidatonya sewaktu rapat Persis di Bogor pada tanggal 17 Juni 1934, Mochammad Natsir menyampaikan tentang "Ideologi Pendidikan Islam" bahwa: "Maju atau mundurnya salah satu kaum bergantung sebagian besar kepada pelajaran dan pendidikan yang berlaku dalam kalangan mereka". 10

Menurutnya bahwa tidak akan ada bangsa yang terbelakang menjadi maju melainkan karena sudah mengadakan

\footnotetext{
9 Thohir Luth, Dakwah dan Pemikiran Muhammad Natsir, h. 40.

10 Thohir Luth, Dakwah dan Pemikiran Muhammad Natsir, h. 94 .
} 
dan memperbaiki pendidikan anak-anak dan generasi pemudanya. Artinya bahwa kemajuan suatu negara sangat bergantung kepada kepedulian negara tersebut terhadap pendidikan. Dengan demikian bahwa pendidikan menjadi tolok ukur peradaban bangsa dan negara. Pendidikan adalah suatu pembinaan jasmani dan rohani yang menuju kepada kesempurnaan akhlak mulianya dan lengkapnya sifat-sifat kemanusiaan dalam arti yang sesungguhnya. Tujuan pendidikan adalah tujuan hidup dalam artian bahwa para pendidik harus dapat membentuk peserta didiknya menjadi manusia yang mengabdi kepada Tuhan dan mencari keridloan-Nya. ${ }^{1}$

Oleh karena itu konsep pendidikan menurut Mochammad Natsir adalah konsep atau prisip utama pendidikan dan muaranya pendidikan adalah tauhid, sesuai dengan tuntunan Al-Qur'an surat Al-'Alaq ayat 1-5 (Q. S: 96/1-5), yang artinya:

"Bacalah dengan (menyebut) nama Tuhanmu Yang Menciptakan. Dia telah menciptakan manusia dari segumpal darah. Bacalah dan Tuhanmulah yang Maha Pemurah. Yang mengajar (manusia) dengan perantaraan kalam. Dia mengajarkan kepada manusia apa yang tidak diketahuinya."

Surat Al-Alaq tersebut di atas memberikan pesan kepada manusia agar senantiasa belajar sebagai bentuk perilaku mengenal dan mengagungkan Tuhan, dan pemikiran Mochammad Natsir tentang pendidikan Islam ini, memandang dan mengusahakan agar umat Islam selalu berpedoman kepada ajaran Al-Qur'an dan Hadits Rasul. Dalam menerima dan mengajarkan ilmu pengetahuan ummat Islam harus

\footnotetext{
${ }^{11}$ M. Natsir, Capita Selecta, Jilid 1, (Jakarta: PT. Abadi dan Yayasan Capita Selecta, 2008), h. $77-82$.
}

senantisa menegakkan syari'at Islam dan mentauhidkan Allah SWT. Seperti juga dijelaskan Mochammad Natsir, bahwa:

"Mengenal Tuhan, mentauhidkan Tuhan, mempercayai dan menyerahkan diri kepada Tuhan harus menjadi dasar bagi tiap-tiap pendidikan yang hendak diberikan kepada generasi yang kita didik, jika kita sebagai guru ataupun ibu bapak, betul-betul cinta kepada anak-anak yang telah dipercayakan Allah kepada kita. ",12

Selain itu Mochammad Natsir juga menjelaskan bahwa:

"Pendidikan dengan tauhid sebagai prinsipprinsip utama, akan memberi nilai tambah bagi manusia dan menumbuhkan kepercayaan pada dirinya serta mempunyai pegangan hidup yang benar. Bagi orang yang tidak menjadikan tauhid sebagai dasar pendidikan dalam arti ia tidak memiliki pegangan hidup yang benar, semakin lama ia memperdalam ilmu, semakin hilang rasa tempat berpijak, apa yang kemarin masih benar, sekarang sudah tak betul lagi. Apa yang betul sekarang, besok sudah salah pula. ",13

Mochammad Natsir mempunyai komitmen yang sangat kuat terhadap Islam dan berbagai organisasi yang menjadikan Islam sebagai komitmen dalam perjuangan. Keberadaan Mochammad Natsir dalam berbagai organisasi Islam adalah dalam rangka melaksanakan komitmennya terhadap Islam untuk kepentingan masyarakat dan negara. Dalam anggaran dasar Partai Masyumi ditegaskan secara gamblang seperti dikutip A. Syafii Ma'arif dari

12 M. Natsir, Capita Selecta, Jilid 1, h. 142, seperti juga dikutif dalam Thohir Luth, Dakwah dan Pemikiran Muhammad Natsir, h. 96.

13 M. Natsir, Capita Selecta, Jilid 1, h. 140, seperti juga dikutif dalam Thohir Luth, Dakwah dan Pemikiran Muhammad Natsir, h. 97. 
Pedoman Perjuangan Partai Masyumibahwa tujuan partai adalah terlaksananya ajaran dan hukum Islam di dalam kehidupan individu, masyarakat, dan negara Republik Indonesia menuju keridhaan Ilahi. Tujuan ini dijabarkan jelas dalam tafsiran anggaran dasar tentang gambaran suatu negara yang berdasarkan Islam,

"Kita menuju kepada baldatun thayyibatun wa Rabbun ghafur, negara yang berkebijakan dan diliputi ampunan Ilahi, di mana negara melakukan kekuasaannya atas musyawarah dengan perataraan wakil-wakil rakyat yang dipilih, di mana kaidah-kaidah kedaulatan rakyat, kemerdekaan, persamaan, tasamuh 'lapang dada', keadilan sosial sebagai yang diajarkan oleh Islam, terlaksana sepenuhnya, di mana kaum muslimin mendapat kesempatan untuk mengatur kehidupan pribadi dan masyarakat sesuai dengan ajaran dan hukum-hukum yang tercantum dalam AlQur'an dan As-Sunnah, di mana golongan keagamaan lainnya memilih kemerdekaan untuk menganut dan mengamalkan agamanya serta mengembangkan kebudayaan di mana seluruh penduduk dari segenap lapisan dapat hidup atas keragaman, terjamin baginya hak-hak azasi manusia, yang termasuk di dalamnya keadilan di lapangan sosial, ekonomi, dan politik, kemerdekaan berpikir dan mengeluarkan pendapat, di mana kemerdekaan menganut dan menjalankan agama satu dan lainnya tidak bertentangan dengan undang-undang negara dan susila. ${ }^{, 14}$

Perjuangan Mochammad Natsir adalah selalu untuk kepentingan ummat dan negaranya. Mochammad Natsir secara maksimal telah memberikan seluruh tenaga dan pikirannya demi kepentingan ummat Islam di Indonesia dan seluruh bangsa Indonesia. Mochammad Natsir berusaha keras

14 Thohir Luth, Dakwah dan Pemikiran Muhammad Natsir, h. 44. untuk menciptakan masyarakat yang berperadaban, berbudi pekerti yang luhur, dan berakhlak islami.

Dalam ulang tahun Masyumi ke-13 surat kabar Harian Abadi memuat tentang pembangunan kehidupan rakyat dan realisasi dari kemakmuran sebagai salah satu hal yang esensial. Harian Abadi menegaskan bahwa dalam pembangunan kehidupan rakyat perlu adanya pemberantasan buta huruf dan buta hati sebagai hal yang utama dalam mengangkat derajat dan kecerdasan bangsa dalam pembangunan demokrasi. ${ }^{15}$

Untuk menghindari perilaku yang tidak bermoral dan tidak berpendidikan, menurut Mochammad Natsir bahwa dalam hidup bernegara landasan demokrasi yang dipakai Mohammad Natsir adalah Islam. Menurutnya Islam harus dijadikan sebagai dasar dalam membangun negara dan hidup bermasyarakat. Islam sangat berfungsi dalam memperjuangkan masyarakat yang demokratis, tentram, dan sejahtera. Begitu pentingnya peran agama dalam hidup bernegara dan bermasyarakat. Peran agama dan keberadaan Tuhan tidak bisa dilihat hanya pada penguasa melainkan juga rakyat untuk dapat mengerem dirinya dan lingkungannya dari tindakan merusak. Dengan keyakinan ini baik penguasa ataupun rakyat mampu menyampaikan kebenaran atau mengakkan amar ma'ruf nahyi munkar dan kritis. Melaksanakan amar ma'ruf nahyi munkar inilah sebagai esensi demokratis. ${ }^{16}$ Fungi demokratis yang selalu berpedoman pada agama dalam mengurus negara dan rakyat setidaknya sandiwara politik akan dapat ditekan semaksimal mungkin dan konflik yang terjadi antarlembaga ataupun antarpartai dapat diminimalisir.

\footnotetext{
15 Harian Abadi, No. 115, Tahun ke-VIII, 5 November 1958.

${ }^{16}$ Lukman Hakiem, ed., op. cit., h. 60.
} 
Perjuangan Mochammad Natsir dalam merealisasikan nilai-nilai agama di sekolah-sekolah atau lembagalembaga pendidikan, di masyarakat, dalam bernegara adalah juga sebagai perjuangannya menentang dan mengkritik sistem sekularisme yang menurutnya sangat bertentangan dengan ajaran Islam. Perjuangan Mohammad Natsir ini karena menginginkan masyarakat agar tidak terjerumus pada paham sekularisme tersebut yang dapat menghancurkan institusi keluarga, institusi negara, kosongnya nilai spiritual, serta merusak lingkungan hidup.

Pemikiran seperti ini sejalan dengan yang diuraikan oleh Mohammad Hatta dalam surat kabar harian $\mathrm{Abadi}^{17}$ yang dimuat dalam beberapa terbitan dalam artikel yang berjudul "Islam dan Pembangunan Masyarakat". Pemikiran Mohammad Hatta sama dengan apa yang diperjuangkan Mohammad Natsir yang sangat memikirkan bagaimana masyarakat Islam memahami Islam tentang hidup bermasyarakat dan bagaimana mestinya membangun masyarakat menurut Islam. Berikut beberapa kutipan dari tulisan Mohammad Hatta dalam surat kabar harian Abadi: ${ }^{18}$

...Islam menghendaki damai. Kita satu sama lain harus kasih sayang seperti dijelaskan dalam Al-Qur'an surat Al-Baqoroh ayat 214. Mari kita susun corak masyarakat Islam yang melaksanakan kehendak Ilahi yang setingi-tingginya. ...Keadilan sosial, untuk mencapai keadilan Ilahi. (Harian Abadi, "Islam dan Pembangunan

\footnotetext{
${ }^{17}$ Mohammad Hatta, "Islam dan Pembangunan Masyarakat", artikel I-IV, Harian Abadi, No. 112-128, tahun ke-VIII, 1958, Koleksi Perpustakaan Nasional, Jakarta.

${ }^{18}$ Mohammad Hatta, "Islam dan Pembangunan Masyarakat", Harian Abadi, tahun ke-VIII, 8 November - 30 November 1958, Koleksi Perpustakaan Nasional, Jakarta.
}

Masyarakat”, tahun ke-VIII, 8 November 1958).

...Mengutip hadits Nabi: "aturlah hidupmu sedemikian rupa seolah-olah kamu akan mati esok hari, tetapi juga seolah-olah kamu akan hidup selamanya"....Kita harus perbaiki diri untuk persiapan akhirat kita. Kita harus perbaiki bumi Allah supaya tercapai keadilan Ilahi. (Harian Abadi, "Islam dan Pembangunan Masyarakat", tahun ke-VIII, 10 November 1958).

...Islam dan pembangunan masyarakat bukanlah suatu masalah yang kecil tapi sangat luas. Kita harus mencari titik berat, jiwa apakah yang diberikan Islam untuk pembangunan masyarakat kita.

...Kita membangun kalau kita berkekeluargaan yang mengutamakan kasih sayang dan menggunakan keadilan Ilahi...Dengan ilmu tentang masyarakat pemimpin kita harus tahu ke mana masyarakat yang semakin berkembang ini dibawa, jangan sudah kaya hilang keisyafannya terhadap masyarakat yang masih buruk. Begitu juga kaum melarat sebaiknya selalu memikirkan bagaimana mau berubah seperti sudah dijelaskan dalam Al-Qur'an surat Ali Imran. (Harian Abadi, "Mari Menyusun Masyarakat Berdasar Islam, Islam adalah Damai, Tidak Mengikuti Jejak Iblis", No. 112, tahun ke-VIII, 30 November 1958).

Dalam pemikiran Mochammad Natsir bahwa Allah telah menganugerahkan kepada manusia dua jenis buku yang harus kita baca (iqro') dan kita pahami. Buku pertama adalah kitab suci yang harus dibaca dan dipelajari karena sarat dengan pesan Ilahiyah yang harus dipahami dan diamalkan. Buku kedua adalah alam semesta, sebagaimana buku pertama, juga harus dibaca, dipelajari, dan dipahami sebaik-baiknya oleh manusia karena mengandung semua hal yang diperlukan untuk dapat survive. Hal ini yang harus dipelajari dengan cermat, 
karena bumi sesungguhnya menyediakan semua sarana yang diperlukan manusia untuk memenuhi kebutuhan pangannya. Dengan demikian seharusnya manusia mengoptimalkan dirinya dalam memahami kedua anugerah tersebut dari Allah. Karena semuanya itu diuntukkan Tuhan bagi manusia. Semua itu dapat meninggikan kehidupan manusia, sehingga kehidupan itu jadi beragam dan bercahaya dan manusia dapat merasakan nikmatnya anugerah Ilahi tersebut. ${ }^{19}$

Dengan demikian pemerintah juga perlu memberdayakan masyarakatnya agar dapat mengolah bumi dan hasilnya untuk dapat dinikmati dalam kehidupan sehingga tidak terpuruk dalam kebodohan, kemiskinan, dan jauh dari hidup sehat.

\section{Penutup}

Dengan melihat sejarah perkembangan pendidikan Islam di Indonesia maka sudah sejak Islam masuk ke Indonesia pendidikan Islam ini bertujuan untuk menegakkan kalimah tauhid sesuai dengan ajaran Al-Qur'an dan Hadits. Selain itu agar bangsa Indonesia tidak hidup dalam kebodohan sehingga tidak menjadi terhinakan oleh bangsa-bangsa lain. Melalui pendidikan dapat meningkatkan derajat dan kemuliaan di dunia dan di akhirat. Mengajarkan ilmu pengetahuan berarti menyeru untuk berbuat baik yakni menggunakan akal pikiran yang dianugerahkan Tuhan kepada manusia. Seperti dalam Al-Qur'an surat Al-Hasyr ayat 59 yang artinya: „Gunakanlah pikiranmu wahai orang yang mempunyai akal". Hal ini adalah karena agama Islam menghargai akal manusia, meletakkan akal pada tempat yang terhormat, menyuruh manusia mempergunakan akal itu untuk memeriksa dan memikirkan

\footnotetext{
${ }^{19}$ M. Natsir, Capita Selecta, Jilid 2, h. 184.
}

keadaan alam dan lingkungan sekitarnya. Seperti dalam hadits dijelaskan bahwa „agama itu adalah akal, tak ada agama bagi seseorang yang tidak menggunakan akal". Beberapa ayat Al-Qur'an juga banyak menyebutkan yang berbunyi „kenapa kamu tidak berpikir?“, ,kenapa kamu tidak ingat?“, kenapa kamu tidak mempergunakan akal?“

Menurut Mochammad Natsir, bahwa pembahasan Islam sangat menyeluruh tidak saja masalah agama, tetapi juga sosial, negara, politik, pendidikan, dan ekonomi. Islam masuk ke Indonesia dapat mempersatukan ideologi dan kekuatan politik melawan kolonialisme. Bagi para pemeluk agama Islam, Islam bukan sekedar agama sebagai tuntunan hidup, melainkan dapat memberikan pengaruh psikologis dan sosial yang tinggi yang dapat menciptakan solidaritas (ukhuwah) yang tinggi di antara pemeluknya. Mochammad Natsir, menggagas konsep dakwah Islam bukan sekedar menyampaikan ajaran Islam, tetapi amar ma'ruf nahi munkar yang di dalamnya mengandung tiga unsur utama yaitu amal perbuatan lisan, aktualisasi ajaran Islam dengan karya nyata, dan kepribadian yang terpuji sebagai sokogurunya. Pemahaman konsep dakwah ini mempunyai implikasi terhadap perubahan masyarakat, baik dari sosiokuturalnya maupun geopolitiknya. Dalam konteks ini, tugas dakwah Islam itu lebih diarahkan sebagai kewajiban pribadi, bukan sebagai kewajiban kolektif. Artinya, semua orang harus berdakwah untuk dirinya, keluarganya, dan masyarakat di mana saja dan kapan saja, supaya dapat memacu adanya 'perubahan', ${ }^{20}$ untuk menciptakan masyarakat yang berperadaban.

\footnotetext{
${ }^{20}$ Thohir Luth, M. Natsir: Dakwah dan Pemikirannya, Gema Insani Press, 1999, hal. 4152
} 
Seperti ditegaskan dalam pidato Presiden Soekarno ketika memberikan kuliah di UNHAS (Universitas Hasanuddin) Makasar pada tahun 1953, bahwa pendidikan yang dibutuhkan itu adalah pendidikan tentang bagaimana cara mengabdi kepada masyarakat, menghasilkan ide-ide yang dapat dinikmati oleh masyarakat, dan bagaimana berguru yang baik agar pendidikan yang didapat dapat berguna bagi masyarakat. ${ }^{21}$

Dengan membangun masyarakat yang cerdas dan bermartabat maka tugas kita sebagai ummat Islam dalam menegakkan dan menyelamatkan bangsa akan lebih bermanfaat dan dapat dirasakan langsung oleh seluruh rakyat Indonesia. Ini akan sesuai dengan tujuan yang diformulasikan dalam AD/ART Masyumi saat Masyumi didirikan sebagai partai politik, yaitu “...Masyumi bertujuan menegakkan Republik Indonesia dan agama Islam" dan ini bagi seorang Masyumi harus istiqomah atau konsisten dalam menegakkan tujuan ini. $^{22}$

Dengan demikian, berdasarkan sumber-sumber sejarah yang dapat saya peroleh dari Surat Kabar Harian Abadi, penerbitan-penerbitan Masyumi, pidatopidato anggota Partai Masyumi, khususnya pidato-pidato Mochammad Natsir, dan buku-buku yang sudah ditulis

\footnotetext{
${ }^{21}$ Setiap memperingati hari ulang tahun Masyumi, tanggal 7 November, Surat Kabar Harian Abadi ini selalu menulis dalam bagian 'Tajuk Rencana' di halaman pertama, tentang tugas manusia sebagai khalifah di bumi dan merupakan seruan bagi anggota Masyumi untuk selalu mengisi hidup dan kehidupannya yang berguna bagi masyarakat dan negara sesuai dengan ajaran Islam. Semua aktivitas Masyumi dalam menegakkan dan menyelamatkan negara dan bangsa atau sebagai partai politik Islam harus berguna untuk kebangkitan dan keselamatan agama, bangsa, dan tanah air. Surat Kabar Harian Abadi, Tahun 1950-1960

${ }^{22}$ Lihat di M. Natsir, Capita Selecta, Jilid 3, lihat juga Surat Kabar Harian Abadi.
}

tentang Masyumi dapat direkonstruksi sebagai sejarah tentang bagaimana kiprah Partai Masyumi pada masa tahun 1950-an, terutama Mochammad Natsir. Mochammad Natsir tidak hanya berjuang di ranah politik tetapi berdasarkan temuan dari sumber-sumber tersebut menunjukkan bahwa ia juga aktif memberikan sumbangan pemikiran dan konsep-konsepnya tentang pentingnya pendidikan yang didasari agama.

Mochammad Natsir tidak hanya menggagas pemikiran secara teoritis, melainkan juga dibuktikan dengan kenyataan, seperti dalam bidang dakwah, penerbitan, pendidikan, sosial-ekonomi, kesehatan, kepesantrenan, kemasjidan, penelitian, pengembangan masyarakat, dan berbagai kegiatan di lingkungan cendekiawan muslim. Mochammad Natsir memprakarsai berdirinya pesantren Daarul Fallah yang didirikan di atas tanah seluas 20,5 hektar di desa Ciampea, Bogor, dan mengembangkan teknologi tepat guna dalam bidang pertanian, pengembangan koperasi, peternakan, kesehatan masyarakat terpadu yang dikoordinir oleh Yayasan Desa bahagia, dengan program pendidikan yang terpadu antara ilmuilmu keagamaan dan teknologi pertanian, manajemen perkoprerasian, perbengkelan dan berbagai ilmu keterampilan lainnya. Pesantren Daarul Fallah telah mempelopori kerja sama dengan pihak luar negeri semenjak tahun 1968, seperti dalam penyediaan fasilitas pendidikan, perbengkelan, peternakan, dsb. Ini merupakan usaha nyata di bidang sosial-ekonomi dan pendidikan ummat Islam. $^{23}$

23 Thohir Luth, Dakwah dan Pemikiran Muhammad Natsir, h. 93-94. 


\section{Daftar Pustaka}

A. Sumber Surat Kabar dan Majalah Abadi, Surat kabar milik Partai Masyumi, 1950-1960.

Berita Masyumi, 1950-1952.

\section{B. Sumber Primer yang Diterbitkan}

Natsir, M. Capita Selecta, Jilid 2, Cetakan Pertama 1957 dan Jilid 3, PT. Abadi, Jakarta 2008.

\section{Buku}

Benda, Harry J., terj., Bulan Sabit dan Matahari Terbit, Jakarta, Pustaka, 1980.

Miriam Budiardjo, Dasar-Dasar Ilmu Politik, Edisi Revisi, PT. Gramedia Pustaka Utama, Jakarta, 2008.

Eriyanto, Analisis Wacana, Yogyakarta, LKIS, 2003.

Encyclopedia of Social Sciences, Vol. 13-14

Feith, Herbert \& Lance Castles, ed., Pemikiran Politik Indonesia 19451965, LP3ES, Jakarta, 1995.

Flournoy, Don Michael, Analisis Isi Surat Kabar Indonesia, Yogyakarta, UGM Press, 1989.

Geertz, Clifford, Abangan, Santri, Priyayi dalam Masyarakat Jawa. Terj., Jakarta, Pustaka Jaya, 1983.

Hakiem, Lukman, ed., 100 tahun Mohammad Natsit: Berdamai dengan Sejarah: Berdamai dengan Sejarah, Penerbit Republika, Jakarta, 2008.

Husein Heikal, Muhammad, Pemerintah Islam, Terj., Pustaka Firdaus, Jakarta, 1990.
Iskandar, Muhammad, Para Pengemban Amanah: Pergulatan Pemikiran Kyai dan Ulama di Jawa Barat 1900-1950, Yogyakarta, Matabangsa, 2001.

Ismail, Ibnu Qoyyim, Kyai Penghulu Jawa: Peranannya di Masa Kolonial, Gema Insani Pers, Jakarta, 1997.

Kartodirdjo, Sartono, Pemikiran dan Perkembangan Historiografi Indonesia: Suatu Alternatif, Jakarta, Gramedia, 1982.

Pendekatan Ilmu Sosial dalam Metodologi Sejarah, Jakarta, Gramedia, 1992.

Pengantar Sejarah Indonesia baru: Sejarah Pergerakan Nasional, dari Kolonialisme sampai Nasionalisme, Jilid 2, Jakarta, Gramedia.

Korver, A.P.E., Sarekat Islam: Gerakan Ratu Adil?, Jakarta, Grafiti Pers, 1985.

Kuntowijoyo, Budaya dan Masyarakat, Tiara Wacana, Yogyakarta, 1999.

Paradigma Islam: Sebuah Interpretasi Untuk Aksi, Bandung, MIzan, 1991. , 'Kebudayaan Indonesia Kontemporer', Makalah Simposium Martabat Manusia Indonesia, Yayasan Sudjatmoko, Jakarta, 23 Januari 1991.

Leirissa, R.Z., et. al., Sejarah Perekonomian Indonesia, Proyek Inventarisasi dan Dokumentasi Sejarah Nasional, Departemen 
Pendidikan dan kebudayaan RI, Jakarta, 1996.

Luth, Thohir, M. Natsir: Dakwah dan Pemikirannya, Jakarta, Gema Insani Press, 1999.

Mubyarto, 'Islam menghadapi Kemiskinan dan Kesenjangan', Makalah Simposium Festival Istiqlal, dalam Panduan Simposium: Islam dan Kebudayaan Indonesia Dulu, Kini, dan Esok, Jakarta, Gedung Indosat, 1991.

Nakamura, Mitsuo, Bulan Sabit Muncul dari Balik Pohon Beringin: Studi tentang Pergerakan Muhammadiyah di Kotagede, Yogyakarta, UGM Press, 1983.

Naquib, Al Atas, Muh., Islam dalam Sejarah dan Kebudayaan Melayu, Bandung, Mizan, 1990.

Nasution, Harun, Pembaharuan dalam Islam: Sejarah Pemikiran dan Gerakan, Jakarta, Bulan Bintang, 1991.

Natsir, M. Capita Selecta, Jilid 1, 2, dan Jilid 3, PT. Abadi, Jakarta 2008.

Niel, Robert van, Munculnya Elit Modern Indonesia, Jakarta, Pustaka Jaya.

Noer, Deliar, Gerakan Modern Islam di Indonesia 1900-1942, Jakarta, LP3ES, 1991.

, Mohammad Hatta: Biografi Politik, LP3ES, Jakarta, 1990.

, Partai Islam di Pentas Nasional: Kisah dan Analisis Perkembangan Politik Indonesia 1945-1965, Bandung, Mizan, 2000.
Pijper, G. F., Penelitian tentang Agama Islam di Indonesia 1930-1950, terj. Jakarta, UI Press, 1992.

Poesponegoro, Marwati Djoened dan Nugroho Notosusanto, ed., Sejarah Nasional Indonesia, Jilid VI, Jakarta, Balai Pustaka, 1984.

Ricklefs, M. C., Sejarah Indonesia Modern, terj., Yogyakarta, UGM Press, 1994.
- Sejarah Indonesia Modern 1200-2004, Serambi, Jakarta, 2001.

Stoddarrd, L., Dunia Baru Islam, Jakarta, Percetakan Negara, 1966.

Sumarjan, Selo, Perubahan Sosial di Yogyakarta, Yogyakarta, UGM Press, 1993.

Suminto, Aqib, Politik Islam Hindia Belanda: Het Kantoor voor Indlandsche Zakken, Jakarta, LP3ES, 1996.

Supomo, Prof. Dr., Undang-undang Dasar Sementara Republik Indonesia, Djakarta, 1950.

Surjomihardjo, Abdurrahman, ed., Beberapa Segi Perkembangan Sejarah Pers di Indonesia, Jakarta, Kompas, 2002.

Tanthowi, Pramono U., Kebangkitan Politik Kaum Santri: Islam dan Demokratisasi di Indonesia 19902000, PSAP, Jakarta, 2005.

Welirang, Franciscus, Revitalisasi Republik: Perspektif Pangan dan Kebudayaan, Grafindo, Jakarta, 2007. 